\title{
福島第一原発事故による避難指示区域における復興拠点の 計画・整備プロセスに関する研究
}

一時限的な居住制限が復興計画に与えた影響の分析一

\section{RESEARCH ON THE PROCESS OF PLANNING AND IMPLEMENTATION RECONSTRUCTION HUB IN EVACUATION AREAS DUE TO FUKUSHIMA DAI-ICH NUCLEAR POWER STATION ACCIDENT}

-Analysis of the influence of temporary residence restriction on disaster reconstruction plan-

\author{
福田昌代*1, 秋田典子*2 \\ Masayo FUKUDA and Noriko AKITA
}

\begin{abstract}
We analyzed the impact of the residence restrictions by the evacuation areas due to the nuclear accident on the content of the disaster reconstruction plans, focusing on the living hubs in Namie, Okuma, Tomioka Towns. Hubs' location changed from outside, to inside towns, to inside the difficult to return areas by the restriction contents. According to the compact city concept, the target municipalities built facilities for daily life at the previously planned hubs. However, setting up hubs in the difficult to return areas does not fit the concept of a compact city, and the positioning of these hubs is ambiguous.
\end{abstract}

Keywords : Fukushima Dai-ich Nuclear Power Station Accident, Evacuation Areas, Hub, Disaster Reconstruction Plan 福島第一原子力発電所事故, 避難指示区域, 拠点, 復興計画

\section{1. 研究の背景と目的}

2011 年 3 月 11 日に発生した東日本大震災による福島第一原子力 発電所 (以下、原発) 事故の発生から 10 年が経過した。原発被災地 においては、長期にわたる居住制限が実施された。放射線による污 染のおそれのある自治体に対し、国は放射線防護を目的として、原 発事故発生翌日の 3 月 12 日に原発から半径 $20 \mathrm{~km}$ 圈内の地域に対 し地域外一避難するよう指示を発令し 1)、住民、行政機能ともに自 治体外を含む当該地域外一の避難が求められた。避難指示が発令さ れた地域では、避難指示区域が解除されるまでの期間は避難指示区 域内一の居住や立入り、事業実施等の日常的な活動が制限された ${ }^{2)}$ このため原発被災地の自治体は、原発事故の収束、放射線量の推移、 避難指示等の国の方針や制度設計の見通しなど、先の状況が分から ない中で模索しながら復興を進めてきた。また、津波被災地におけ る災害危険区域は、市町村の条例により範囲や規制の内容を定める のに対し、原発被災地の避難指示区域の範囲や居住制限の内容、避 難指示区域内の生活環境の回復などの復興の方向性は、国が決定す る。このため、市町村が行う復興まちづくりとスピード感にずれが 生じるなど、復興計画づくりに困難が伴うと考えられる。

これまでに原発被災地を対象とした研究には、復興事業の評価や 住民の意識調査、事業再開やゾーニングの設定方法に関するものが 挙げられる。まず、復興事業の進捗や評価に関する研究として、川
崎 ${ }^{3}$ は、原発事故から約 5 年後の復興拠点の整備及び計画の実態を 報告している。また、續橋ら ${ }^{4}$ ) 浪江町、川崎 ${ }^{5}$ は富岡町の復興拠点 の居住者を対象として、生活環境に対する意識調査を行い、いずれ も帰還を選択できるほど生活環境が回復していないことを指摘して いる。李ら ${ }^{6}$ は、南相馬市小高区を対象として、第 2 次、第 3 次産 業の事業所再開の実態を調査し、事業所再開の課題として賠償金に より生活が担保された状況にあることや、震災前までは農業と事業 の複合生業であり、放射線の影響による農業の再開が難しい状況で 事業のみを再開することが困難であることを指摘している。窪田 7) は、原発被災地でのゾーニングに関して、被曝を抑えることを目的 とする避難だけでなく、賠償や除染、復興などを含む国の考え方で 決められてきたことを指摘している。

また、原発被災地の被災の特徵や復興の状況を時系列に整理し、 報告したものとして、「東日本大震災における実効的復興支援の構築 に関する特別調查委員会最終報告（第 2 部 福島編）」8)があるが、 福島の被災の特徵を概観し、原発被災 12 市町村それぞれの復興経 緯、人口の移動、復興計画の概要等を報告するにとどまっており、 居住を制限する避難指示区域の指定が復興まちづくりにどのような 影響を与えたかという観点から分析を行った研究は見られない。 そこで本研究では、原発事故により居住制限を伴う避難指示区域 (以下、帰還困難区域、居住制限区域および避難指示解除準備区域
*1 千葉大学大学院園芸学研究科 博士後期課程 · 修士 (学術)

*2 千葉大学大学院園芸学研究院 教授・博士 (工学)
Grad. Student, Graduate School of Horticulture, Chiba University, M.ph.

Prof., Graduate School of Horticulture, Chiba University, Dr.Eng. 
を合わせて避難指示区域とする）が行政区域の全域に指定された自 治体を対象に、復興まちづくりの軸となる拠点に着目し、避難指示 区域の指定や解除とこれに基づく居住制限の内容が、市町村の復興 計画の内容に与えた影響を明らかにすることを目的とする。本研究 で対象とする拠点とは、住民の生活を支える行政、商業、医療など の生活サービス機能を持つ場所であり、帰還困難区域に指定された 原発被災地に位置付けられた以下の 3 つの拠点に着目する。(1)当該 自治体内の居住制限区域または避難指示解除準備区域に設定された 拠点（以下、元町内拠点）(2避難先自治体内などの当該自治体外に 設置することが復興計画等で位置づけられていた拠点（以下、町外 拠点)、(3)当該自治体内の帰還困難区域内に新たに設定された特定復 興再生拠点区域（以下、新町内拠点）。

\section{2. 対象および方法}

\section{2-1. 対象自治体の選定}

本研究の対象地は、原子力災害対策本部が、原発事故が収束した と判断したことを受け示した「ステップ2の完了を受けた警戒区域 及び避難指示区域の見直しに関する基本的考え方及び今後の検討課 題について $(2011$ 年 12 月 26 日)」（以下、見直し方針）9）に基づく 警戒区域および計画的避難区域の再編（以下、区域再編）に伴い、 行政区域の全域が避難指示区域となり、かつ帰還困難区域に一定以 上の人口が居住していた浪江町、大熊町、富岡町の 3 町とした (Table 1、Fig.1)。大熊町、富岡町は行政区域の全域が、浪江町は中心市街 地を含む行政区域の約 $60.8 \%$ 注 1 )が原発から $20 \mathrm{~km}$ 圈内に含まれて おり、原発事故発生翌日に住民および行政機能は、原発から半径 $20 \mathrm{~km}$ 圈外一避難を指示された。さらに、警戒区域および計画的避 難区域再編まで当該区域内への立入りが原則禁止された。なお、大 熊町には福島第一原発が、富岡町には福島第二原発が立地し、1960 年代以降、それぞれの原発の建設や稼動のために人口が増加し、3 町 では原発事故発生時にも一定の人口が維持されていた。

双葉町も大熊町と同様に福島第一原発が立地しており、3 町と同 様に全域が避難指示区域かつ一定の人口規模があるが、2020 年 12 月末時点で行政区域の約 $96 \%$ が䚻還困難区域であり 10 、残りの約 $4 \%$ の域には生活環境の形成を目的とした拠点整備は計画されて いないため11)、本研究では対象外とした。

本研究の対象である浪江町、大熊町、富岡町が位置する福島県浜 通りは、JR 常磐線、国道 6 号、常磐自動車道注 2) が縦断し南北の交 通の利便性が高く、原発事故前から日常生活において南北方向に自 治体間のつながりが強い地域であった。このため、浜通りの南端に 位置し、福島県内第 1 位の人口（2011 年 3 月時点）12)を有するいわ き市は、これらの自治体の広域的中心都市であり、浜通りの拠点と して周辺自治体の生活サービスを担ってきた。また、南相馬市は、 浜通りで第 2 の人口規模を有し (2011 年 3 月時点) 12 )、浜通りの北 部側の拠点となっている。

\section{2-2. 研究の方法}

本研究は、復興庁や環境省等の行政機関の資料や各町の復興計画 を用いた文献調查、町担当者へのヒアリング調查および現地調查に より実施した。文献調查では、各町のホームページから復興計画お よび拠点整備に関する個別計画（以下、復興計画等）（Table 2）を 入手し、復興計画等における拠点整備に係る内容を分析した。また、
Table 1 Outline of the target area / 対象地の概要 12)13)14)15)

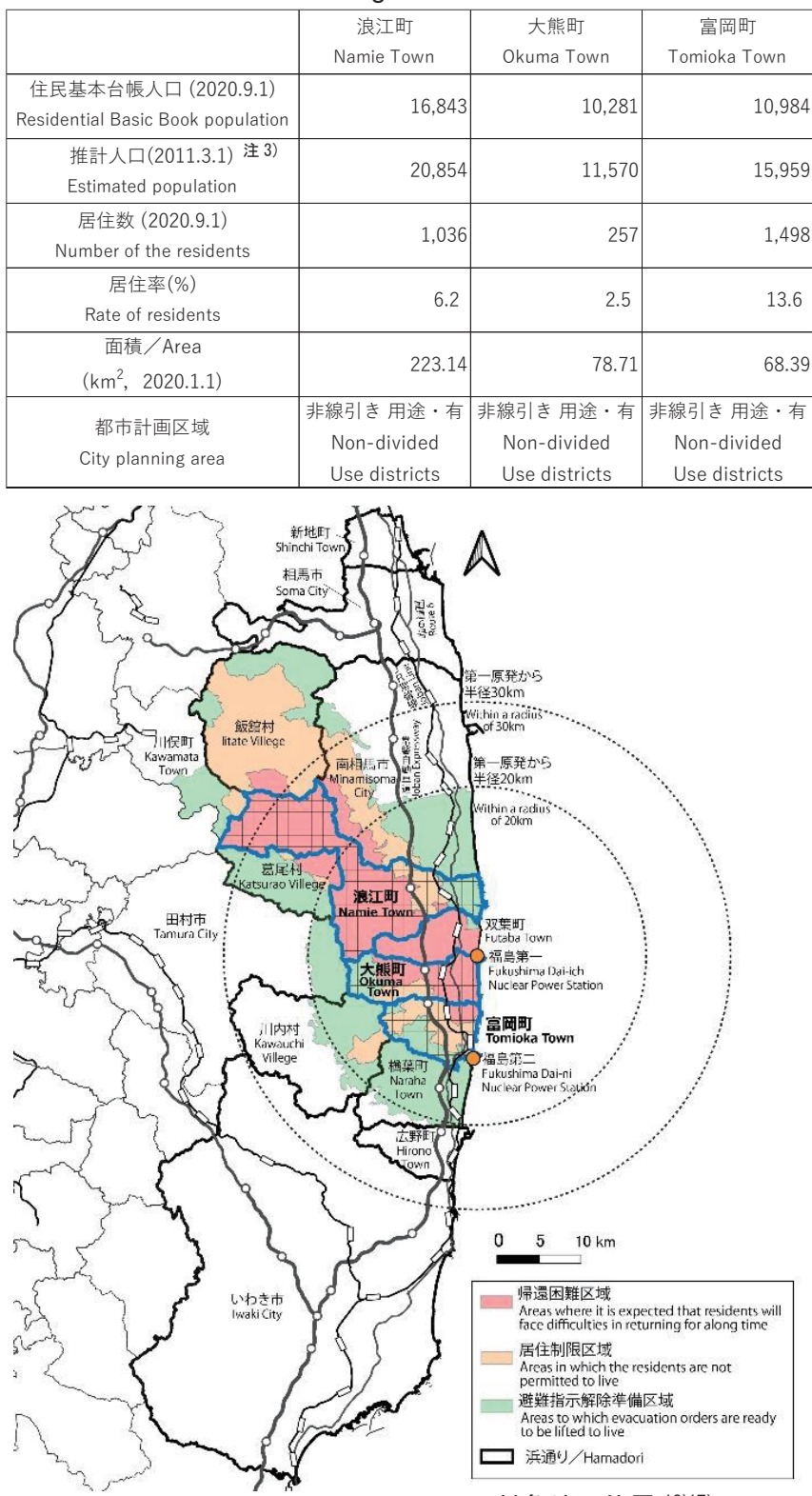

Fig.1 Location of the target area/対象地の位置 16)17)

拠点の計画・整備を進める上で背景となると考えられる、避難指示 区域、除染に関する制度の内容、避難指示期間中の各町の行政機能 の避難状況を国の資料や各町の震災記録誌等の資料から把握した。 ヒアリング調查および現地調查は、2018 年 8 月、 2019 年 $6 \sim 7$ 月、 2020 年 6 月、 8 月、 10 月、 2021 年 1 月に実施した。ヒアリング調 查は、直接または電話や電子メールを用いて行い、復興計画策定や 改訂の経緯、除染や拠点整備の進捗状沉、拠点整備の内容を調査し た。現地調查は、各町の拠点の現状を把握した。

\section{3．原発被災地における居住制限の概要 3-1. 避難指示区域}

再編前の警戒区域および計画的避難区域、再編後の避難指示区域 の概要を Table 3 に示す。原子力災害対策本部は 2011 年 4 月に、 国から 3 月 12 日に発令された原発から半径 $20 \mathrm{~km}$ 圈内一の避難指 示を引き継ぎ、原発から半径 $20 \mathrm{~km}$ 圏内を警戒区域に、それ以遠で 
Table 2 Target disaster reconstruction plans and the other plans /対象とする復興計画等

\begin{tabular}{|c|c|c|c|c|c|c|c|c|c|c|c|c|}
\hline & \multicolumn{2}{|c|}{$\begin{array}{c}\text { 復興計画(1) } \\
\text { Disaster reconstruction plan(1) }\end{array}$} & \multicolumn{2}{|c|}{$\begin{array}{c}\text { 復興計画(2) } \\
\text { Disaster reconstruction plan(2) }\end{array}$} & \multicolumn{2}{|c|}{$\begin{array}{c}\text { 復興計画(3) } \\
\text { Disaster reconstruction plan(3) }\end{array}$} & \multicolumn{2}{|c|}{$\begin{array}{c}\text { まちづくり計画 } \\
\text { Reconsrtaction hub plan }\end{array}$} & \multicolumn{2}{|c|}{$\begin{array}{c}\text { 特定復興再生拠点区域復興再生計画 } \\
\text { The Specified Reconstruction and Revitalization } \\
\text { Bases plan }\end{array}$} & \multicolumn{2}{|l|}{$\begin{array}{c}\text { その他 } \\
\text { Other plan }\end{array}$} \\
\hline & $\begin{array}{l}\text { 名称 } \\
\text { Name }\end{array}$ & \begin{tabular}{|c|} 
策定年月 \\
Date of \\
fomulation \\
\end{tabular} & $\begin{array}{l}\text { 名称 } \\
\text { Name }\end{array}$ & \begin{tabular}{|c|}
$\begin{array}{c}\text { 策定年月 } \\
\text { Date of } \\
\text { fomulation }\end{array}$ \\
\end{tabular} & $\begin{array}{l}\text { 名称 } \\
\text { Name }\end{array}$ & \begin{tabular}{|c|} 
策定年月 \\
Date of \\
fomulation
\end{tabular} & $\begin{array}{l}\text { 名称 } \\
\text { Name }\end{array}$ & \begin{tabular}{|c|} 
策定年月 \\
Date of \\
fomulation \\
\end{tabular} & $\begin{array}{l}\text { 名称 } \\
\text { Name }\end{array}$ & \begin{tabular}{|c|} 
策定年月 \\
Date of \\
fomulation \\
\end{tabular} & $\begin{array}{l}\text { 名称 } \\
\text { Name }\end{array}$ & \begin{tabular}{|c|} 
策定年月 \\
Date of \\
fomulation \\
\end{tabular} \\
\hline $\begin{array}{c}\text { 浪江町 } \\
\text { Namie } \\
\text { Town }\end{array}$ & \begin{tabular}{|l} 
浪江町復興計画 \\
(第一次) \\
Disaster \\
reconstruction \\
plan(1st edition), \\
NamieTown \\
\end{tabular} & $\begin{array}{r}2012 \text { 年 } 10 \text { 月 } \\
\text { Oct., } 2012\end{array}$ & \begin{tabular}{|l} 
浪江町復興計画 \\
(第二次) \\
Disaster \\
reconstruction \\
plan(2nd edition), \\
NamieTown \\
\end{tabular} & $\begin{array}{c}\text { 2017年3月 } \\
\text { Mar.,2017 }\end{array}$ & $\begin{array}{l}\text { 浪江町復興計画 } \\
\text { (第三次) } \\
\text { Disaster reconstruction } \\
\text { plan(3nd edition), } \\
\text { NamieTown }\end{array}$ & \begin{tabular}{|c|} 
2021年3月 \\
Mar.,2021
\end{tabular} & $\begin{array}{l}\text { 浪江町復興まちづ } \\
\text { くり計画 } \\
\text { Reconsrtaction } \\
\text { hub plan,Namie } \\
\text { Town }\end{array}$ & \begin{tabular}{|c|} 
2014年3月 \\
Mar. 2014 \\
\end{tabular} & $\begin{array}{l}\text { 特定復興再生拠点区域復興再生計画 } \\
\text { 福島県双葉郡浪江圢 } \\
\text { The Specified Reconstruction and } \\
\text { Revitalization Bases plan, Namie Town, } \\
\text { Futaba Country, pref. Fukushima }\end{array}$ & $\mid \begin{array}{r}\text { 2017年12月 } \\
\text { Dec., 2017 }\end{array}$ & $\begin{array}{l}\text { 浪江町中心市街地再生 } \\
\text { C計画 } \\
\text { Central urban area } \\
\text { regeneration plan, } \\
\text { Namie Town }\end{array}$ & $\begin{array}{c}\text { 2017年3月 } \\
\text { Mar.,2017 }\end{array}$ \\
\hline $\begin{array}{c}\text { 大熊町 } \\
\text { Okuma } \\
\text { Town }\end{array}$ & \begin{tabular}{|l} 
第一次大熊町 \\
復興計画 \\
Disaster \\
reconstruction \\
plan(1st edition), \\
OkumaTown \\
\end{tabular} & $\begin{array}{l}\text { 2012年9月 } \\
\text { Sept.,2012 }\end{array}$ & \begin{tabular}{|l} 
大熊町第二次 \\
復興計画 \\
Disaster \\
reconstruction \\
plan(2nd edition), \\
OkumaTown \\
\end{tabular} & $\mid \begin{array}{r}\text { 2015年3月 } \\
\text { Mar.,2015 }\end{array}$ & \begin{tabular}{|l|} 
大熊町第二次復興 \\
計画改訂版 \\
Disaster reconstruction \\
plan(2nd edition \\
revised), \\
OkumaTown \\
\end{tabular} & \begin{tabular}{|c|} 
2019年3月 \\
Mar.,2019
\end{tabular} & $\begin{array}{l}\text { 大熊町復興まちつ゚ } \\
\text { くりピジョン } \\
\text { Reconsrtaction } \\
\text { hub plan,Okuma } \\
\text { Town }\end{array}$ & \begin{tabular}{|r|} 
2014年3月 \\
Mar.,2014
\end{tabular} & $\begin{array}{l}\text { 特定復興再生拠点区域復興再生計画 } \\
\text { 福島県双葉郡大熊町 } \\
\text { The Specified Reconstruction and } \\
\text { Revitalization Bases plan, Okuma } \\
\text { Town, Futaba Country, pref. } \\
\text { Fukushima }\end{array}$ & \begin{tabular}{|r|} 
2017年10月 \\
Oct., 2017
\end{tabular} & - & \\
\hline $\begin{array}{c}\text { 富岡町 } \\
\text { Tomioka } \\
\text { Town }\end{array}$ & \begin{tabular}{|l} 
富岡町災害復興計画 \\
(第一次) \\
Disaster \\
reconstruction \\
plan(1st edition), \\
TomiokaTown \\
\end{tabular} & $\begin{array}{l}\text { 2012年9月 } \\
\text { Sept.,2012 }\end{array}$ & \begin{tabular}{|l} 
富岡町災害復興計画 \\
(第二次) \\
Disaster \\
reconstruction \\
plan(2nd edition), \\
TomiokaTown \\
\end{tabular} & \begin{tabular}{|c|} 
2015年6月 \\
June, 2015
\end{tabular} & \begin{tabular}{|l|} 
富岡町災害復興計画 \\
(第二次)後期 \\
Disaster reconstruction \\
plan(2nd edition) for \\
latter half, \\
TomiokaTown \\
\end{tabular} & $\begin{array}{c}\text { 2020年3月 } \\
\text { Mar.,2020 }\end{array}$ & \begin{tabular}{|l|} 
富岡町復興まちづ \\
くり計画 \\
Reconsrtaction \\
hub plan,Tomioka \\
Town
\end{tabular} & \begin{tabular}{|r|} 
2014年3月 \\
Mar.,2014
\end{tabular} & $\begin{array}{l}\text { 特定復興再生拠点区域復興再生計画 } \\
\text { 福島県双葉郡富岡㽗 } \\
\text { The Specified Reconstruction and } \\
\text { Revitalization Bases plan Tomioka } \\
\text { Town, Futaba Country, pref. } \\
\text { Fukushima }\end{array}$ & $\begin{array}{l}\text { 2018年2月 } \\
\text { Feb., 2018 }\end{array}$ & \begin{tabular}{|l} 
富岡町再生・発展の先 \\
駆けアクションプラン \\
〜復興拠点整備計画 \\
Reconsrtaction hub \\
development \\
plan,Tomioka Town
\end{tabular} & $\begin{array}{r}\text { 2015年9月 } \\
\text { Sept., 2015 }\end{array}$ \\
\hline
\end{tabular}

Table 3 Outline of restricted areas and evacuation areas /警戒区域および避難指示区域の概要 ${ }^{2)}$

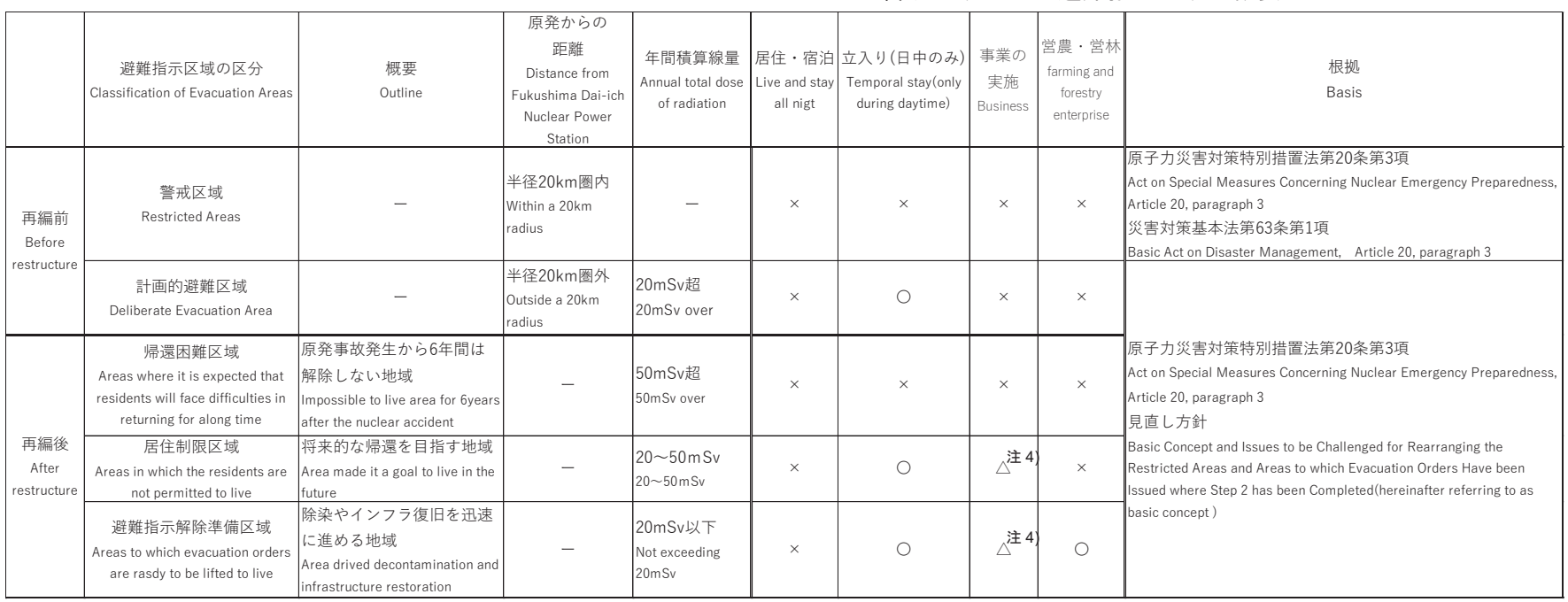

年間積算線量が $20 \mathrm{mSv}$ を超えるおそれのある地域を計画的避難区 域として設定した。区域再編は自治体ごとに実施された。

区域再編前の警戒区域では、原則宿泊・居住および立入りが、計 画的避難区域では日中の立入りは可能、その他の行為は禁止されて いた。区域再編後の帰還困難区域では、原則として全ての行為が禁 止され再編前の警戒区域と同様の扱いとされた。居住制限区域と避 難指示解除準備区域では、宿泊・居住は制限されたが、日中の立入 りや復旧・復興のための事業実施は可能となった ${ }^{2)}$

これらの避難指示区域の解除は、自治体との協議をもとに原子力 災害対策本部が決定する。浪江町および富岡町では避難開始から 6 年経過した 2017 年 3 月に、大熊町では約 8 年が経過した 2019 年 4 月に帰還困難区域を除く避難指示区域が解除された。

\section{3-2. 特定復興再生拠点区域}

帰還困難区域内で除染やインフラ整備を進め、将来的に居住可能 とする区域である。自治体が、特定復興再生拠点区域（本研究では 新町内拠点と定義）の設定および当該区域内の除染やインフラ復旧 などの環境整備に係る計画である特定復興再生拠点区域復興再生計 画（以下、新町内拠点計画）を策定し、内閣総理大臣が認定する。 新町内拠点を設定できる地域の条件として、放射線量低下の見通し や、居住や経済活動に適した地形、効率的に整備可能な規模である
こと等がある 18)。また、新町内拠点計画の認定から概ね 5 年後に新 町内拠点内の避難指示を解除することが目標とされており、現在は 国により新町内拠点内の除染や家屋解体注 5)が進行している。なお、 新町内拠点の一部である大熊町の大野駅周辺および富岡町の夜の 森駅周辺地域は、2020 年 3 月の常磐線全線開通に合わせ、先行的に 帰還困難区域が解除された ${ }^{19)}$ 。

\section{4. 各町の避難の状況}

原発には、 2011 年 3 月 11 日午後 3 時 35 分に、高さ $10 \mathrm{~m}$ を超え る津波が襲来し、午後 3 時 37 分から 42 分にかけて全電源が停止し た。全電源喪失により原子炉を冷却するための注水の状況を確認で きなくなったことを受け、 3 月 11 日午後 7 時 3 分に内閣総理大臣 が原子力緊急事態宣言を行い、続いて午後 9 時 23 分に原発から半 径 $3 \mathrm{~km}$ 圈内に避難指示を発令した。翌日の 3 月 12 日午前 5 時 44 分には半径 $10 \mathrm{~km}$ 圈内、 3 月 12 日午後 6 時 25 分には半径 $20 \mathrm{~km}$ 圈 内一避難が必要な範囲が拡大していき、さらに 2 日後の 3 月 13 日 には、原発から半径 $20 \sim 30 \mathrm{~km}$ 圈内に屋内退避指示が発令された 1$)$ (Table 4)。3 町では、これらの避難指示の発令を受け、いずれも複 数回に渡り行政機能と住民を避難させた（Fig.2）。 
Table 4 Evacuation orders issued immediately after Fukushima Dai-ichi Nuclear Power Station (NPS) Accident 原発事故発生直後に発令され避難指示 ${ }^{1)}$

\begin{tabular}{|c|c|c|c|c|c|}
\hline \multicolumn{2}{|c|}{ 日付 Date } & 時刻 Time & 対象範围 Target area & $\begin{array}{c}\text { 指示内容 } \\
\text { Content of order }\end{array}$ & $\begin{array}{c}\text { 本文中での表記 } \\
\text { Description in body text }\end{array}$ \\
\hline \multirow[t]{9}{*}{$\begin{array}{l}\text { 2011年 } \\
\text { The year } \\
2011\end{array}$} & \begin{tabular}{|l|} 
3月11日 \\
11th,March
\end{tabular} & & $\begin{array}{l}\text { 第一原発から半径3km圈内 } \\
\text { Withn a 3km radius of Fukushima } \\
\text { Dai-ichi NPS }\end{array}$ & $\begin{array}{l}\text { 避難指示 } \\
\text { Evacuation order }\end{array}$ & \\
\hline & & & $\begin{array}{l}\text { 第一原発から半径3 10km圈内 } \\
\text { With a radius beteween } 3 \text { and } \\
10 \mathrm{~km} \text { from Fukushima Dai-ichi NPS }\end{array}$ & \begin{tabular}{|l} 
屋内退避 \\
Shelter indoors \\
order
\end{tabular} & \\
\hline & \begin{tabular}{|l|} 
3月12日 \\
12th, March
\end{tabular} & $5: 44$ & $\begin{array}{l}\text { 第一原発から半径10km圈内 } \\
\text { With a } 10 \mathrm{~km} \text { radius of Fukushima } \\
\text { Dai-ichi NPS }\end{array}$ & $\begin{array}{l}\text { 避蜼指示 } \\
\text { Evacuation order }\end{array}$ & $\begin{array}{l}10 \mathrm{~km} \text { 圈 } \\
\text { Evacua } \\
\text { Within }\end{array}$ \\
\hline & & & $\begin{array}{l}\text { 第二原発から半径3km圏内 } \\
\text { Within a } 3 \mathrm{~km} \text { radius of Fukushima } \\
\text { Dai-ni NPS }\end{array}$ & $\begin{array}{l}\text { 避鞛指示 } \\
\text { Evacuation order }\end{array}$ & \\
\hline & & & $\begin{array}{l}\text { 第二原発から半径3 10km圈内 } \\
\text { Within a radius beteween } 3 \text { and } \\
10 \mathrm{~km} \text { from Fukushima Dai-ni NPS }\end{array}$ & \begin{tabular}{|l} 
屋内退避 \\
Shelter indoors \\
order
\end{tabular} & \\
\hline & & $17: 39$ & $\begin{array}{l}\text { 第二原発から半径10km圈内 } \\
\text { With a 10km radius of Fukushima } \\
\text { Dai-ni NPS }\end{array}$ & $\begin{array}{l}\text { 避難指示 } \\
\text { Evacuation order }\end{array}$ & \\
\hline & & $18: 25$ & $\begin{array}{l}\text { 第一原発から半径20km圈内 } \\
\text { Within a 20km radius of Fukushima } \\
\text { Dai-ni NPS }\end{array}$ & $\begin{array}{l}\text { 避䍴指示 } \\
\text { Evacuation order }\end{array}$ & $\begin{array}{l}20 \mathrm{~km} \text { 圈内避蜼指示 } \\
\text { Evacuation order for } \\
\text { Within a radius of } 20 \mathrm{~km}\end{array}$ \\
\hline & $\begin{array}{l}\text { 3月15日 } \\
\text { 15th,March }\end{array}$ & 11:01 & $\begin{array}{l}\text { 第一原発から半径 } 20 \sim 30 \mathrm{~km} \text { 圈内 } \\
\text { Within a radius beteween } 20 \text { and }\end{array}$ & $\begin{array}{l}\text { 屋内退避 } \\
\text { Shelter indoors }\end{array}$ & $\begin{array}{l}30 \mathrm{~km} \text { 圈内屋内退避指示 } \\
\text { Shelter indoors order for }\end{array}$ \\
\hline & & & 30km from Fukushima Dai-ichi NPS & order & within \\
\hline
\end{tabular}

\section{4-1. 浪江町注 6)20}

浪江町は、3 月 12 日に国から $10 \mathrm{~km}$ 圏内避難指示が発令された 後、住民へ 2 回にわたり避難を指示した。同日午前 8 時 40 分より $10 \mathrm{~km}$ 圈内の避難所の住民を浪江町内の $10 \mathrm{~km}$ 圏外の避難所へ移動 させ、行政機能を午後 6 時 0 分に浪江町役場津島支所八移転した。 さらに、同日午後 6 時 25 分に発令された $20 \mathrm{~km}$ 圈内避難指示を受 け、第一原発から半径 $20 \mathrm{~km}$ 圏内に滞在している住民を $20 \mathrm{~km}$ 圏外 に位置する浪江町内の津島地区へ移動させた。3 月 15 日午前 4 時 30 分には浪江町外の二本松市への再避難を決定し、住民、行政機能 ともに二本松市へ移動した。浪江町と二本松市は災害時の協定等を 結んでいなかったが行政区域が隣接しているため 21)、浪江町長が二 本松市長入直接避難者受け入れを要請し、二本松市長から承諾を受 け、二本松市を避難先として決定した。約 1 ケ月後の 4 月 4 日に二 本松市役所東和支所内に浪江町役場二本松事務所が設置され、行政 機能が置かれた。また、桑折町に浪江町桑折出張所（2011 年 9 月 ～)、2011 年 11 月からは、福島市に浪江町福島出張所、本宮市に浪 江町本宮出張所、いわき市に浪江町いわき出張所および南相馬市に 浪江町南相馬出張所が開設された。しかし、2 年後の 2013 年 4 月 には避難指示区域の再編や町内人の一時立入業務を担当寸る帰町準 備室が、次いで道路や上下水道などの復旧業務を担当する復旧事業 課 22)が元の浪江町役場内で業務を開始した。行政機能は、居住制限 区域および避難指示解除準備区域が解除された避難開始から約 6 年 後の 2017 年 4 月に全面再開し、二本松市から浪江町内に全ての行 政機能が戻った。

\section{4-2. 大熊町注 6)23}

大熊町では、3 月 12 日の国による $10 \mathrm{~km}$ 圈内避難指示の直後に、 国から電話で $10 \mathrm{~km}$ 圏外へ避難するように直接連絡を受けた。福島 県からは大熊町の西側に隣接する田村市へ避難するように連絡があ り、田村市へ住民、行政機能ともに避難した。住民の避難は 3 月 12 日の午前 6 時 30 分頃から行われ、避難先は田村市のほか郡山市、 小野町、三春町に分散した。行政機能は、3月 12 日午後 7 時 30 分 までに田村市内に設置された。さらに、大熊町は原発事故が収束に 向かう見通しがない中で、行政機能を移転し、町民がまとまって帰
還を待てる落ち着いた環境が必要と考え、3 月 25 日に会津若松市へ 再避難することを決定した。避難先の検討は、大熊町教育長が担当 し、学校再開を考慮し利用できる廃校があること、子じも、保護者 を含め数千人単位で受け入れられる自治体規模であること、原発周 辺自治体の避難状況から避難先は福島県西部に限られること等の条 件が合致したため避難先として決定した。4月 3〜4 日に住民が田村 市などの避難所から会津若松市へ移動、4 月5 日に会津若松市役所 追手町第二庁舎内に大熊町会津若松出張所が開所し、行政機能が設 置された。会津若松市以外には、2011 年 10 月にいわき市に大熊町 いわき連絡事務所（2013 年 12 月から大熊町いわき支所）、2012 年 10 月に二本松市に大熊町中通り連絡事務所（2016 年 4 月に郡山市 に移転）が設置され、いわき市や中通り地域に避難している住民へ 行政サービスを提供した。また、元の大熊町内には、2013 年 4 月に 大熊町役場現地連絡事務所が開設され、避難期間中の町内パトロー ル等の拠点となったほか、2016 年 4 月に大熊町大川原連絡事務所 が開設され、一時帰宅した住民に対し住民票の写しや所得証明書等 の発行を開始した。避難の開始から約 8 年後の居住制限区域および 避難指示解除準備区域解除直後の 2019 年 5 月以降は、大熊町内の 大川原地区に新たに建設された大熊町役場新庁舎で業務を開始し、 全ての行政機能が会津若松市から大熊町へ戻った。これに伴い、大 熊町現地連絡事務所および大熊町大川原連絡事務所は 2019 年 3 月 に閉鎖した。

\section{4-3. 富岡町注 6)24)25)}

富岡町では、3 月 12 日に国から発令された $10 \mathrm{~km}$ 圈内避難指示 を受け、3 月 12 日午前 6 時 0 分頃に西側に隣接する川内村へ避難 者の受け入れを要請し、住民の移動を開始した。富岡町を含めた浜 通り地域を縦断する国道 6 号の決壊の情報があったことや福島第二 原発も危険な状態であり、富岡町から南側に避難できなかったこと から川内村への避難を決定した。住民は川内村のほか三春町などの 川内村周辺自治体へ、行政機能は川内村内に避難し川内村と合同の 災害対策本部が設置された。さらに、3月 15 日に国から 20〜 $30 \mathrm{~km}$ 圏内屋内退避指示が発令され、川内村全域が屋内退避の対象エリア に含まれた。国は川内村からの避難要請を行わなかったが、富岡町、 川内村の独自の判断で、2 自治体がともに再避難を決定した。避難 先として、福島県から南会津または群馬県片品村方面を指示された が、避難に要する時間や高齢者の体力を考慮すると、これらの地域 への避難は難しいと判断し、独自に避難先を探すこととした。そし て、富岡町長が郡山市に所在する「ビッグパレットふくしま（管理 主体 : 福島県)」へ受け入れ要請をし、3 月 16 日に富岡町と川内村 が合同で郡山市へ再避難した。富岡町は、4月 22 日にビックパレッ 卜ふくしま内に富岡町郡山出張所（2011 年 12 月から富岡町郡山事 務所，郡山市内に仮設建物を新設し移転）を開設して行政機能を置 き、 2011 年 12 月にいわき市内に富岡町いわき出張所 (2013 年 7 月 から富岡町いわき支所)、三春町に富岡町三春出張所、大玉村に富岡 町大玉出張所を設置した。また、2013 年 7 月から富岡町に隣接する 楢葉町内に富岡町楢葉分室を設置し、下水道等の復旧を担う復旧課 および除染計画や都市計画等に関する業務を担う復興推進課が入居 した。2015 年 10 月から復旧課および復興推進課が富岡町内で業務 を開始、避難開始から約 6 年後の居住制限区域および避難指示解除 準備区域が解除された 2017 年 3 月に富岡町内で富岡町役場が全面 


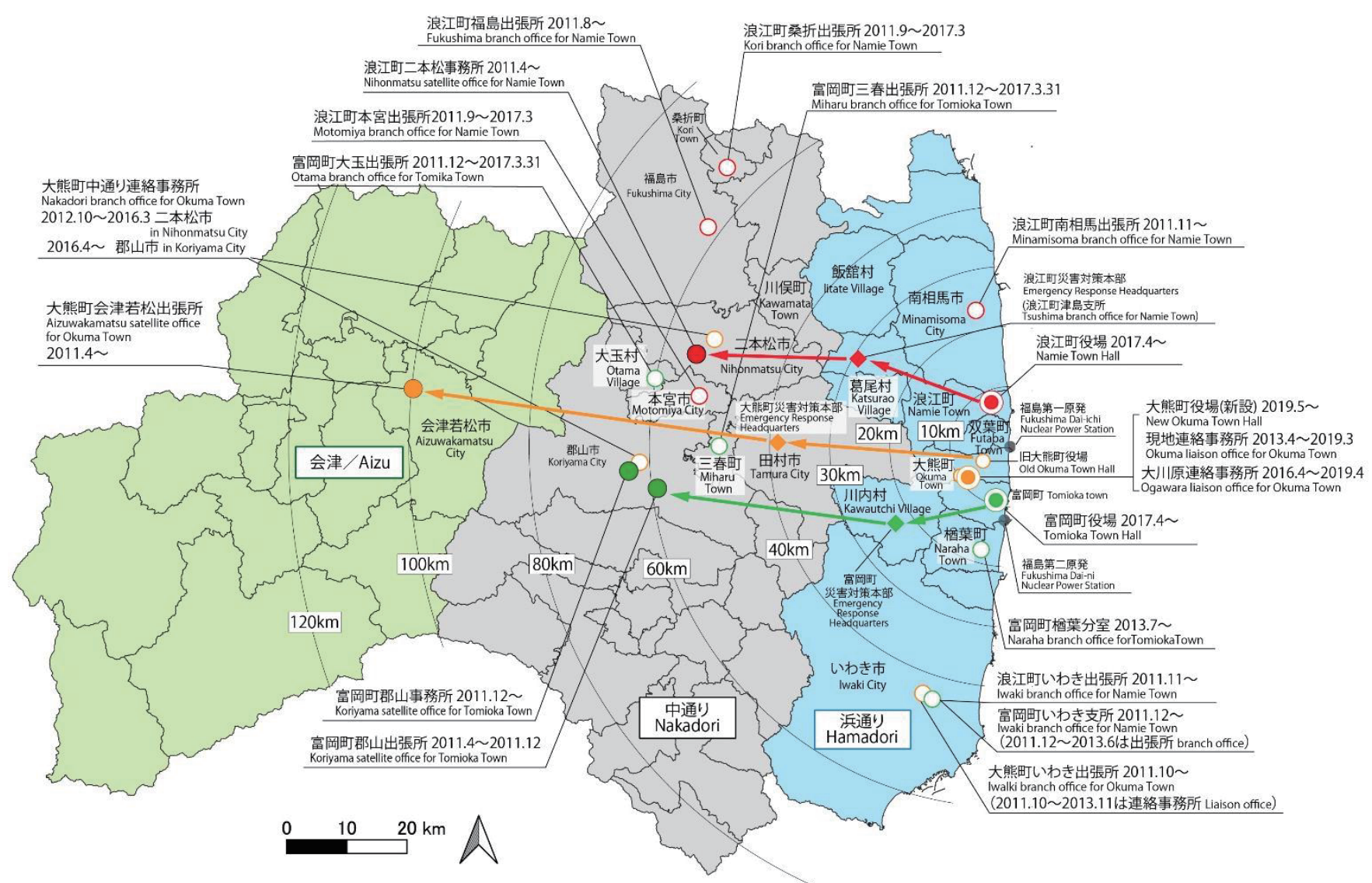

Fig.2 Relocation destination of administrative functions for target local government 3 町の行政機能の移転先 ${ }^{16) 20(23) 24) 25) 26) ~}$

再開し、全ての行政機能は富岡町内に戻った。

\section{4-4. 小括}

3 町は、町外での行政機能の再開に至るまでに、町内の避難指示 が発令された区域外の地域や隣接自治体への一時的な避難を経て、 2 段階での避難を行っていた。また、避難先の決定において、3 町は 独自に避難者の受入れを要請し、避難先を決定していた。福島県に よる指示などもあり、本庁機能の避難先は避難元と生活圈の異なる 西側の中通りや会津の自治体であったが、3 町は共通して避難元自 治体と同じ浜通りの拠点であり、避難者が多かったいわき市注 7)にも 支所や出張所を設置していた。また、浪江町は原発事故前に通学や 買い物先であった南相馬市にも出張所を設置しており、各自治体の 広域の生活圏が避難先に影響を及ぼしていた。

\section{5. 拠点の計画・整備の経過}

\section{5-1. 復興計画等の策定}

対象とする 3 町の復興計画等の策定状況を示す (Table 5 復興計 画等)。3 町はいずれも 2012 年度に復興計画第一次を策定後、複数 回改訂するとともに元町内拠点整備に係る個別計画を策定してきた。 復興計画第一次の策定時期は、大熊町および富岡町が 2012 年 9 月、 浪江町が同年 10 月であった。一方で、2012 年は町外一避難中かつ 区域再編や本格除染の開始前であり、各町は復興計画第一次の中で、 原発事故の収束や区域再編、除染等の復興に向けた国の対応や工程 が不透明であることから情勢の変化に応じ見直しを行うことを示し ている。
2014 年 3 月には、3 町は住民一避難元の復興の方向性を示すた め、避難元の町に設置する元町内拠点に特化したまちづくり計画を 策定した。復興計画は拠点整備のほか、福祉、教育、商工業等の多 岐の分野の復興への取り組みを示した計画であるが、まちづくり計 画は元町内拠点整備を中心としており、3 町は原発事故発生後初め て避難元の町に整備する元町内拠点の具体的な計画内容を示した。 復興計画第二次以降の復興計画の策定時期は自治体により異なり、 避難指示期間中に改訂 (大熊町、富岡町)、避難指示解除と同時期に 改訂 (浪江町、大熊町)、避難指示解除後に改訂（浪江町、富岡町） している。

\section{5-2. 復興計画等における拠点の内容}

3 町の拠点の内容について、整備位置に着目して復興計画等の改 訂に伴う変化を明らかにする（Table 5 拠点位置）。

浪江町と富岡町の復興計画第一次 (2012 年) およびまちづくり計画 (2014 年)、大熊町復興計画第一次 (2012 年)、まちづくり計画 (2014 年) および復興計画第二次（2015 年）では、町外拠点が位置づけら れていた。3 町は、復興計画第一次 (2012 年) において、災害公営 住宅をはじめ、行政、教育機能、商業施設などが整備され町民がま とまって生活できるニュータウン型の町を、避難先自治体を含めた 避難元自治体外に町外拠点として整備するという内容を掲げていた。 町外拠点の位置は、各町の行政機能が避難した自治体であり、浪江 町は二本松市、大熊町は会津若松市、富岡町は郡山市に計画された。 これに加えて、浪江町はいわき市と南相馬市、富岡町はいわき市を 町外拠点設置の候補地とした。大熊町は復興計画第一次 (2012 年) 
Table 5 Disaster reconstruction planning process /復興計画の策定プロセス

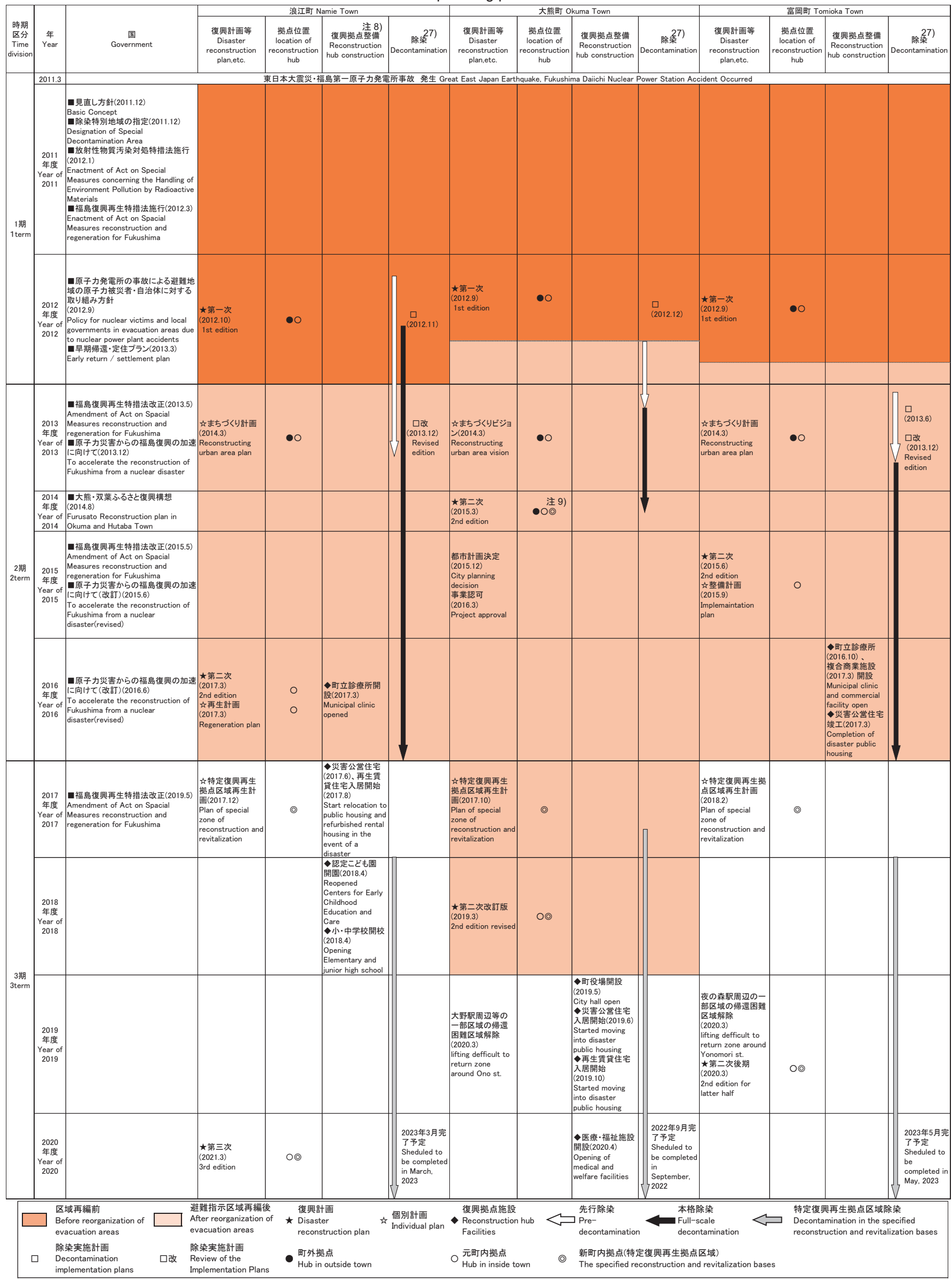


策定から 5 年後を目標に、町外拠点を会津若松市からいわき市に移 転するとした。3 町ともにいわき市を町外拠点の位置に選定してお り、その理由として住民アンケートでの希望が多かったことや 3 町 から近く気候が似ていることが挙げられていた。区域再編後に策定 されたまちづくり計画以降は、元町内拠点の計画内容を示したうえ で、町外拠点の位置付けや元町内拠点と町外拠点の関係が示されて いた。浪江町は、町外拠点と浪江町の 2 地域での生活も含めて想定 していること、大熊町は居住拠点としての町外一の災害公営住宅整 備を掲げており、元町内拠点が具現化するとともに町外拠点の役割 の縮小や緩やかな位置づけに変化している。富岡町担当者へのヒア リング調查では、復興計画第一次 (2012 年) 策定時は区域再編前で あり町への帰還を想定していない内容であったが、区域再編に伴い 町内一の立入りや除染が可能となったことから元町内拠点の計画を 始めることができた。また、既往文献では、原発避難者受け入れに よる人口、世帯数の増加に伴う都市施設や交通施設の整備が伴わな い状況にあることが指摘されており 28)、町外拠点の位置づけの変化 は、避難者を受け入れている自治体側の都市計画一の配慮もあった と考えられる。

元町内拠点は、 3 町ともに復興計画第一次 (2012 年) から位置づ けているが、大熊町は復興計画第一次 $(2012$ 年) において、元町内 拠点を除染やインフラ復旧の拠点として位置づけられており、まち づくり計画策定時に、居住のための拠点へと機能が変化した。

また、新町内拠点について、浪江町、富岡町では、新町内拠点計 画策定後の復興計画の改訂時に復興計画へ新町内拠点を位置づけて いた。大熊町は、新町内拠点の制度成立前の 2015 年 3 月策定の復 興計画 (2015 年) に、のちに新町内拠点となった地域を元町内拠点 に次ぐ第二の拠点として示していた。ただし、この計画では、「将来 の居住地や、廃炉・復興に向けた事業者のための事業用地」といっ た土地利用の方向性を記述するにとどまっている。

\section{5-3. 元町内拠点および新町内拠点の立地状況}

元町内拠点および新町内拠点の立地状況は、放射線量の分布や原 発事故発生前の基盤整備の状況により各町で異なった。また、東日 本大震災からの復興の基本方針（2011 年 8 月 11 日東日本大震災復 興対策本部改定）で示されたコンパクトなまちづくりを方針として 拠点を計画、整備した。Fig.3 に、原発事故発生前の中心市街地注 10 ) と元町内拠点および新町内拠点の位置関係を示す。

浪江町の元町内拠点は、震災前の中心市街地と元町内拠点が同じ 位置である。浪江町に対するヒアリング調查から、中心市街地が町 内で放射線量が低いエリアであったことと、帰還する住民に対し町 の風景を抜本的に変えることは考えられなかったため、中心市街地 を元町内拠点としたことが把握できた。中心市街地内で活用できる 施設や土地を活用した施設整備を行っており、中心市街地内空地へ の交流・情報発信拠点（道の駅）の建設や既存の雇用促進住宅の改 修により福島再生賃貸住宅を整備している。2016 年度中に町営診療 所、災害公営住宅、福島再生賃貸住宅、認定こども園および小中併 設校の整備を開始し、2017 年 8 月までに災害公営住宅および福島 再生賃貸住宅の入居を開始した。2020 年 8 月には交流・情報発信拠 点施設の一部を供用開始した。

一方、浪江町の新町内拠点は、町中央部に位置する室原地区、未 森地区、町北西部に位置する津島地区の 3 地区約 661ha（3.7\%)
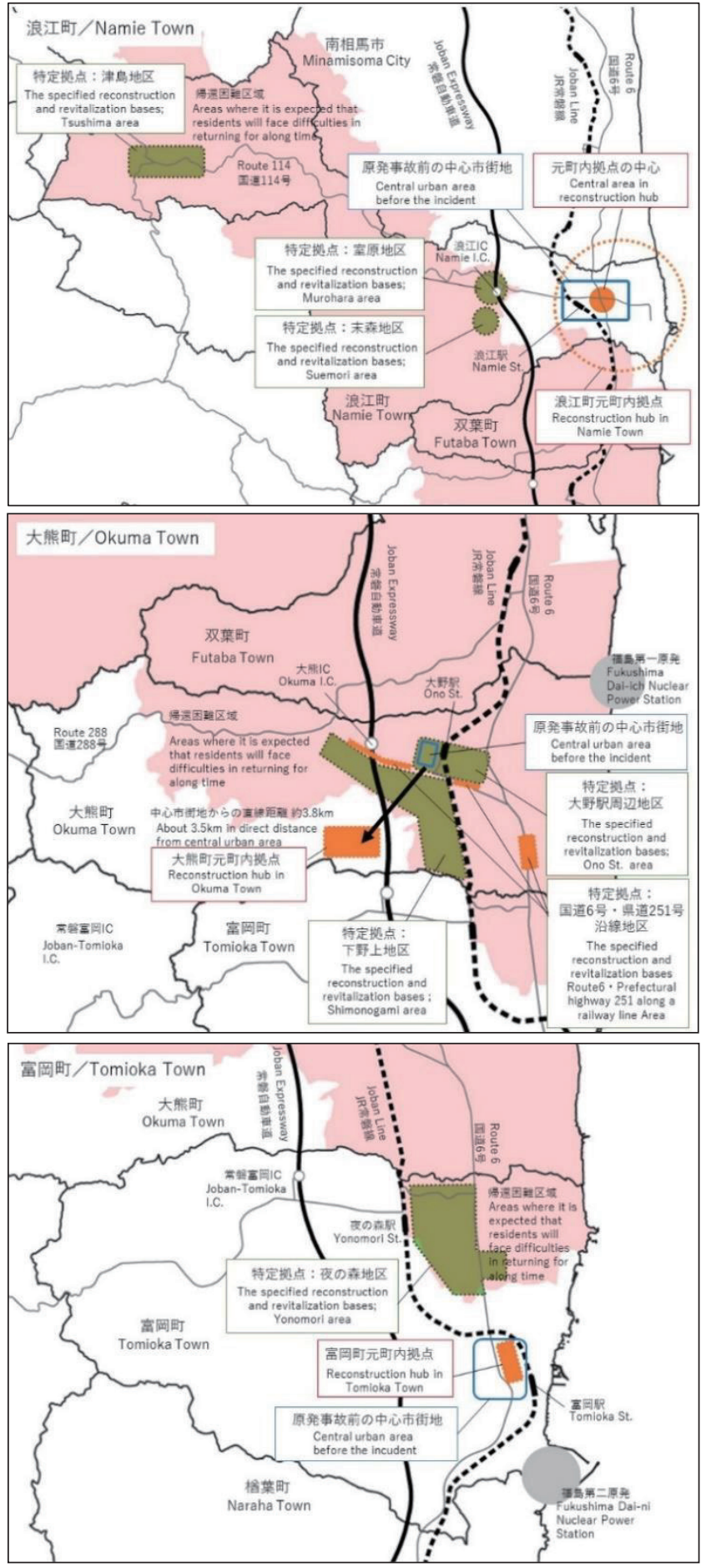

Fig.3 Location of existing central urban areas, reconstruction hubs and the specified reconstruction and revitalization bases

中心市街地、元町内拠点および新町内拠点の立地注 11)16)17)

注 12)注 13)に指定されている。3 地区ともに帰還者の住宅再建および地 域の行事や集まりの拠点となる集会所の復旧、営農再開を目的とし たゾーンが設定されている。加えて、室原地区は常磐自動車道浪江 IC、国道や県道の結節点である立地を生かした産業・物流施設の立 地、津島地区は 1956 年の浪江町合併前の旧津島村の中心として、 町役場津島支所や交流施設であるつしま活性化センター、津島診療 所といった公共施設の再開を図ることが計画されている。 
大熊町の元町内拠点は、中心市街地から約 $3.8 \mathrm{~km}$ 注 14 離れた大川 原地区に設置された。大熊町では、中心市街地を含む町の約 $60 \%$ 10) が帰還困難区域に指定されたため、町内でも比較的放射線量が低い エリアが元町内拠点の位置として選定された。元は農地だった土地 を 2017 年 12 月から造成し、 2019 年 5 月に町役場新庁舎、 2020 年 4 月までに災害公営住宅、福島再生賃貸住宅、医療・福祉施設を開 設した。2020 年 10 月時点で交流施設が建設中、幼小中一貫校を計 画中である。一団の土地に上述の施設を集約し整備している。

一方、大熊町の新町内拠点は、大野駅周辺地区と下野上地区およ び国道 6 号・県道 251 号沿線地区の 3 地区の約 860ha（17.6\%) 注 12)に指定されている。大野駅周辺地区は原発事故前からの町の中 心として帰還住民や廃炉関連企業従事者の住宅、企業用地および駐 車場の整備、既存公共施設の再開が計画されている。下野上地区は、 居住、営農再開といった従前の土地利用を活かし、廃炉関連事業、 福島イノベーションコースト構想関連事業等の産業集積を図る区域 である。国道 6 号沿線は、沿道型の生活利便施設（コンビニ、ガソ リンスタンド等）の再開・整備を図るとされている。

富岡町の元町内拠点は、原発事故発生前からの中心市街地に位置 し、1995 年 7 月に都市計画決定された ${ }^{29)}$ 曲田土地区画整理事業施 行中のエリアに設置された。建築物がほとんど建っておらず空地が 多かったこと、町内でも放射線量が低いエリアであったことから選 定された。2016 年度中に町営診療所、複合商業施設、災害公営住宅 の建設に着手し、居住制限区域および避難指示解除準備区域の解除 予定時期に合わせ 2017 年 3 月までに完成させた。

一方、富岡町の新町内拠点は、夜の森地区の約 $390 \mathrm{ha}(48.8 \%)$ 注 12) に指定されている。夜の森地区は、夜の森駅を基点に市街地が 形成され、原発事故前は生活・居住系機能拠点 29)であった。夜の森 駅周辺は、居住機能の再生と桜などの観光資源を活用した居住と観 光交流が共存する生活環境として帰還者の住宅再建や集会所等の復 旧、整備が計画されている。その周辺エリアは営農再開や農地転用 による廃炉関連事業、福島イノベーションコースト構想関連事業等 の産業集積の検討、既存商業施設の再開を図るとされている。

\section{5-4. 小括}

3 町は、東日本大震災からの復興の基本方針で示されたコンパク 卜なまちづくりを拠点整備の基本方針として、元町内拠点を計画、 整備した。中心市街地の放射線量が比較的低かった浪江町、富岡町 は従前の中心市街地に拠点を位置づけ、浪江町は既存建物の改修や 中心市街地内の空き地を活用し、富岡町は土地区画整理事業中の区 域を利用して拠点を整備した。中心市街地が帰還困難区域となった 大熊町は中心市街地から離れた集落内の一団の土地に、災害公営住 宅や公共施設を集約して整備した。このように、元町内拠点の整備 は、国が示した復興の方針と合致する複合的でコンパクトな拠点と して構想、建設された。

一方、第 2 の拠点とも言える新町内拠点は、住宅再建や整備、公 共施設の復旧、営農再開のほか産業集積が計画されているが、町内 における位置づけは曖昧なものとなっている。これは、すでに元町 内拠点の計画や整備が進み、日常生活に必要な機能が元町内拠点に 備えられており、新町内拠点に配置する機能を想定しづらい状況で あるためだと考えられる。

\section{6. 結論}

本研究では、原発被災地における避難の実態および居住制限制度 が復興計画の中でも特に軸となる拠点整備の計画策定に与えた影響 を明らかにした。

まず、行政機能の避難先の選定は、福島県からの指示もあったが 基本的には各町が独自に判断し、他自治体への要請も独自に実施し ていた。行政機能の避難先は、放射線による被害を避けつつも、元 の自治体から遠くならない、西側の会津や中通りの自治体であった。 しかし、生活圈である浜通り沿いに避難した住民も多かったことか ら、3 町はいわき市にも支所や出張所を設置した。

次に、各町の拠点の内容は、居住制限の内容により以下のように 変化した。

町内への立入が原則禁止されていた区域再編前には、3 町は復興 計画に町外の拠点の設置を記載していた。町外拠点の位置は、各町 の行政機能が避難した自治体のほか、3 町ともにいわき市に、浪江 町はいわき市に加え南相馬市を掲げていた。上記の通り、いわき市 は浜通りの拠点であり、特に大熊町、富岡町の住民は通学や買い物 といった日常生活で利用してきた。このように、規模が大きく広域 の中での拠点であり、原発事故前から住民が通学や買い物といった 日常生活で利用してきた自治体は、被災した小規模自治体の住民の 受け血として機能している実態が明らかになった。

区域再編が完了寸ると、町内への立入りが可能となり、3 町は元 町内拠点の計画を策定し整備を開始した。3 町の元町内拠点は、国 が示した地域づくりの方針である「コンパクトなまちづくり」とし て、災害公営住宅や公共施設を集約して整備され、元町内拠点の位 置は、中心市街地の放射線量が比較的低かった浪江町、富岡町は中 心市街地に、中心市街地が州還困難区域となった大熊町は中心市街 地から離れた農村部となった。

居住制限区域および避難指示解除準備区域が解除され、帰還困難 区域内で新町内拠点の整備を可能とする制度が成立すると、3 町は 新町内拠点を設定した。3 町の新町内拠点の計画内容は、帰還者の 住宅再建、企業従事者など新しい住民向けの住宅整備、既存公共施 設の復旧、営農再開のほか、3 町ともに物流・産業用地としての土 地利用が想定されている。新町内拠点は自治体からの帰還困難区域 の取扱いを検討するよう要望を受けて30)創設された制度であるが、 住宅や公共施設といった日常生活に必要な機能は寸でに元町内拠点 に整備されており、3 町のような小規模な自治体では、 2 つ目の拠 点の設置を想定することが難しく、位置づけが曖昧な状態となって いた。

今後は、復興計画等の策定・改訂におけるそれらの位置づけや拠 点位置選定の経緯、整備内容の変化を、当該計画が検討された背景 を含めて調查し、避難指示区域に指定された自治体が、住民や行政 機能が分散しかつ元の居住地には居住制限なされている状況下で、 どのように復興を進めてきたのかを明らかにしてゆきたい。

\section{謝辞}

本研究は科研 $19 \mathrm{H} 02308$ および 19H02307、住友財団研究助成 （研究の一部）を受けたものである。 
参考文献

1) Independent committee for verification Fukushima No.1 Nuclear power plant factory Accident: Survey and verification report, pp.23-25,188-193, Discover 21, Inc. 2012.3

福島原発事故独立検証委員会: 福島原発事故独立検証委員会調査・検証報 告書, pp.23-25,188-193, ディスカヴァー・トゥエンティワン, 2012.3 (in Japanese)

2) Department of supporting nuclear disaster victims in Cabinet Office: Reorganization of evacuation order area, 2013.10 (in Japanese)

内閣府原子力被災者生活支援チーム：避難指示区域の見直しについて, 2013.10

3) Kawasaki K.: Actual conditions of reconstruction bases in 12 municipalities that residents were forced to evacuate from home because of the Nuclear Power Plant accident Five years after the Fukushima Daiichi Nuclear Power Plant accident, Summaries of Technical Papers of Annual Meeting, Architectural Institute of Japan, Urban Planning, pp.33-36, 2016.7 (in Japanese)

川崎興太：原発避難 12 市町村の復興拠点の実態一福島原発事故から約 5 年 が経過した現在一, 日本建築学会大会学術講演梗概集, 都市計画, pp.33-36, 2016.7

4) Tsuzukihashi K., Kawasaki K.: A study of current status of living environment and residents in town center of Namie Town after lifting of evacuation orders, Journal of the City Planning Institute of Japan, Vol.53, No.2, pp.215-223, 2018.10 (in Japanese)

續橋和樹, 川崎興太：避難指示解除後の浪江町中心市街地における生活環 境の復旧・再生状況と帰還者の生活実態に関する研究, 都市計画論文集, 53 巻 2 号, pp.215-223, 2018.10

5) Kawasaki K.: Actual conditions of returnees in areas by the nuclear disaster in Fukushima after the lifting of evacuation orders: A case study of disaster public housings in Tomioka Town, Summaries of Technical Papers of Annual Meeting, Architectural Institute of Japan, Architectural Planning and Design, pp.95-98, 2018.7(in Japanese) 川崎興太：避難指示解除後における原子力被災地の帰還者の生活実態 福 島県富岡町曲田地区災害公営住宅の居住者に関する事例研究, 日本建築学 会大会学術講演梗概集, 建築計画, pp.95-98, 2018.7

6) Lee M., Kubota A.: The study on the resurgence of the regional business places in the areas affected by the earthquake, tsunami and the nuclear power plant disaster Focus on the secondary and the tertiary industries in Odaka area, Minamisoma city, where is in the zone in preparation for the lifting of the evacuation order, Journal of the City Planning Institute of Japan, Vol.51, No.3, pp.1054-1061, 2016.10 (in Japanese)

李美沙, 窪田覀矢: 原発複合被災地における事業再開に関寸る研究一避難 指示解除準備区域に指定された南相馬市小高区の第 2 次 ・第 3 次産業を対 象として一, 都市計画論文集, Vol. 51, No.3, pp.1054-1061, 2016.10

7) Kubota A.: STUDY ON ZONING IN NUCLEAR POWER PLANT DISASTER AREA Three terms consisting of emergency evacuation, temporary shelter and protracted refuge in Fukushima Daiichi Nuclear Power Station, Journal of Architecture and Planning (Transactions of AIJ), Vol.84, No.763, pp.1947-1956, 2019.9 (in Japanese)

窪田亜矢：原発被災地域におけるゾーニングに関する研究 福島第一原発 被災地域の緊急避難・応急避難・長期化避難の三つの期間を対象として, 日 本建築学会計画系論文集, 第 84 巻, 第 763 号, pp.1947-1956, 2019.9

8)2016nendo Nihonkenchikugakkaitaikai (Kyushu) Sogo kenkyukyogikai "Fukushima no genjyo to fukko no kadai": Higashinihondaishinsai niokeru jikkoteki fukkoshien no kochiku ni kansuru tokubetsutyosa iinkai saisyuhokoku (Dai 2bu), pp. ii -17- ii -43, 2016.8 (in Japanese)

2016 年度日本建築学会大会 (九州) 総合研究協議会「福島の現状と復興の 課題」: 東日本大震災における実効的復興支援の構築に関する特別調査委 員会最終報告（第 2 部 福島編）, pp. ii - 17- ii - 43, 2016.8

9) Nuclear Emergency Response Headquarters: Regarding the basic concept and future issues regarding the review of the warning area and evacuation order area following the completion of step 2, 2011.12.26 (in Japanese)

原子力災害対策本部：ステップ 2 の完了を受けた警戒区域及び避難指示区 域の見直しに関する基本的考え方及び今後の検討課題について,
2011.12.26

10) Department of supporting nuclear disaster victims in Cabinet Office: Difficult to live zone, 2013.10 (in Japanese)

内閣府原子力被災者生活支援チーム, 帰還困難区域について, 2013.10

11) Futaba Town: Basic plan for hub of reconstruction in Futaba Town, 2016.3 (in Japanese)

双葉町：双葉町内復興拠点基本構想, 2016.3

12) Fukushima prefecture: Estimated population Fukushima prefecture, 2011.3 and 2020.9 (in Japanese)

福島県: 福島県推計人口, 2011.3 および 2020.9

13) Namie Town website: Jinko Setai, Chyomin no hinan jyokyo (accessed 2020.10.2) (in Japanese)

https://www.town.namie.fukushima.jp/life/12/64/

浪江町ホームページ：人口・世帯, 町民の避難状況（参照 2020.10.2）

Okuma Town website: Kyojyu Hinan jyokyo (accessed 2020.10.2) (in Japanese)

https://www.town.okuma.fukushima.jp/life/1/9/164/

大熊町ホームページ：居住・避難状況（参照 2020.10.2）

Tomioka Town website: Ken naigai no hinan jyokyo (accessed 2020.10.2) (in Japanese)

https://www.tomioka-town.jp/saigai_fukko/2201.html

富岡町ホームページ：県内外の避難・居住先別人数（参照 2020.10.2）

14) Geospatial Information Authority of Japan: National prefectures, cities, towns and villages area survey (2020.1.1)

https://www.gsi.go.jp/KOKUJYOHO/MENCHO/backnumber/GSI-

menseki20200101.pdf (accessed 2020.10.2)

国土地理院：全国都道府県市町村面積調(2020.1.1 時点)（参照 2020.10.2)

15) Department of City Planning in Civil Engineering section in Fukushima prefecture: Annual report for City Planning, p.9,12, 2019.3.31 (in Japanese)

福島県土木部都市計画課：令和元年度都市計画年報, p.9,12, 2019.3.31

16) Geospatial Information Authority of Japan: Digital National Land Information (administrative district 2020.1.1, expressway 2019.12.31, operated railway for 1950.1.1-2019.12.31, emergency transport road 2015.7), 2016.3-2020.3 (in Japanese)

国土地理院：国土数值情報(行政区域 2020.1.1 時点，高速道路 2019.12.31 時点, 鉄道 1950.1.1 2019.12.31に運航していた鉄道路線, 緊急輸送道路 2015.7 時点), 2016.3-2020.3

17) METI website: Assistance of Residents Affected by the Nuclear Incidents, Evacuation Areas, Areas to which evacuation orders have been issued 2013.8.7 (accessed 2019.10.19) (in Japanese)

https://www.meti.go.jp/earthquake/nuclear/pdf/130807/130807_01c.pdf 経済産業省ホームページ：原子力被災者支援，避難指示等，川俣町におけ る避難指示区域の見直しについて, 避難指示区域の概念図 (2013 年 8 月 7 日時点）（参照 2019.10.19）

18) Reconstruction Agency Japan website:

Tokuteifukkosaiseikyotenkuikisaiseikeikaku no seido gaiyo (accessed 2021.5.11) (in Japanese)

https://www.reconstruction.go.jp/topics/main-cat1/sub-cat1-

4/saiseikyoten/material/200401_kyotenseidogaiyou.pdf

復興庁ホームページ：特定復興再生拠点区域再生計画の制度概要 (2021.5.11 参照)

19) Reconstruction Agency Japan website: Tokuteifukkosaiseikyoten no seibi jyokyo, 2021.4.1(accessed 2021.5.11) (in Japanese)

https://www.reconstruction.go.jp/topics/main-cat1/sub-cat1-

4/210401_kyotenseibizyoukyou.pdf

復興庁ホームページ：特定復興再生拠点区域の整備状況, 2021.4.1 時点(参 照 2021.5.11)

20) Namie Town: Disaster response report, pp.14-31,61, 2017.3

浪江町：浪江町震災記録誌, pp.14-31,61, 2017.3 (in Japanese)

21) Institute of scientific approaches for fire \& disaster: Higashinihondaisinsai kanren tyosa (2013nen) p.32 (accessed 2021.5.11) (in Japanese)

https://www.isad.or.jp/information_provision/information_provision/h25

一般財団法人消防防災科学センター：東日本大震災関連調査（2013 年）編, 
p.32（参照 2021.5.11）

22) Namie Town: Public relations magazines Namie, April in 2013, pp.6-7, 2013.4.1 (in Japanese)

浪江町：広報なみえ 2013 年 4 月号, p.6-7, 2013.4.1

23) Okuma Town: Disaster response report, pp.54-83, 2017.3 (in Japanese) 大熊町：大熊町震災記録誌, pp.54-83, 2017.3

24) Tomioka Town: Disaster response report 1st edition, pp.21-63, 2015.3 (in Japanese)

富岡町：富岡町東日本大震災・原子力災害の記憶と記録, pp.21-63, 2015.3

25) Tomioka Town: Disaster response report 2nd edition, pp.23-53, 2019.3 (in Japanese)

富岡町：富岡町東日本大震災 - 原子力災害の記憶と記録 II , pp.23-53, 2019.3

26) Fukushima prefecture website: Information link to 59 Municipalities in Fukushima prefecture (accessed 2021.5.29) (in Japanese) https://www.pref.fukushima.lg.jp/site/iju-tokyo/city-town-vill.html 福島県ホームページ: 福島県内 59 市町村情報リンク（参照 2021.5.29）

27) Ministry of the Environment: The plan of decontamination within the special area (Namie Town), 2012.11 (Partially revised, 2013.12) (in Japanese)

環境省：特別区域内除染実施計画（浪江町）, 2012.11（2013.12一部改訂）

Ministry of the Environment: The plan of decontamination within the special area (Okuma Town), 2012.12 (in Japanese)

環境省：特別区域内除染実施計画（大熊町）, 2012.12

Ministry of the Environment: The plan of decontamination within the special area (Tomioka Town), 2013.6 (Partially revised, 2013.12) (in Japanese)

環境省：特別区域内除染実施計画（富岡町），2013.6（2013.12 一部改訂）

28) Saito M.: An Approach to Influence on City Planning by Accepting Evacuees due to Nuclear Accident Focusing on the Change of Population and Land Use, Targeting Iwaki City Fukushima Prefecture, Journal of the City Planning Institute of Japan, Vol.53, No.3, pp.919-926, 2018.10 (in Japanese)

齋藤充弘：原子力発電所事故避難者受け入れ等に伴う都市計画一の影響に ついて一人口と土地利用変化に着目した福島県いわき市を対象として一, 都市計画論文集, Vol.53, No.3, pp.919-926, 2018.10

29) Fukushima prefecture: Master plan for Tomioka Urban area, 2004.5 (in Japanese)

福島県：富岡都市計画都市計画区域の整備、開発保全の方針, 2004.5

30) Nuclear Emergency Response Headquarters Reconstruction Promotion Council: Concept of handling difficult to return zone, 2016.8.31 (in Japanese)

原子力災害対策本部復興推進会議：帰還困難区域の取扱いに関する考え方, 2016.8.31

31) NEXCO East Japan website: Joban Expressway Overview (accessed 2021.6.4) (in Japanese)

https://www.e-nexco.co.jp/pressroom/cms_assets/pressroom/2021/05/27 /01.pdf

NEXCO 東日本ホームページ：常磐自動車道の概要（参照 2021.6.4）

32) Fukushima prefecture: Master plan for Namie Urban area, 2004.5 (in Japanese)

福島県：浪江都市計画都市計画区域の整備、開発保全の方針, 2004.5

注

注 1) QGIS を用いて測定。浪江町の北西部に位置する津島地区は原発から $20 \mathrm{~km}$ 圈外であり、一時的に住民、行政機能の避難先となった（第 3 章参 照）。また、区域再編までは計画的避難区域に指定されており、日中の立入 りは可能であった。

注 2) 2015 年 3 月に常磐富岡 IC〜山元 IC 間が開通し、常磐自動車道が全線 開通した（参考文献 31 )

注 3） 2010 年国勢調查による人口に毎月の住民基本台帳による転入・転出者 数及び出生・死亡者数を加減することにより得た数值。

注 4）居住者を対象とする事業の実施は不可。

注 5）富岡町担当者へのヒアリングによると、居住制限区域および避難指示解 除準備区域の家屋解体では解体家屋の除染を行ってから解体する必要があ ったが、新町内拠点内の解体家屋は家屋の除染を実施せずに解体可能とな
った。

注 6）参考文献が付されていない限り、4-1〜4-3 の内容は、各町の震災記録 誌（参考文献 20,23-25）に記載されている情報をもとに記述した。

注 7）参考文献 13)23)24)25)を用いて著者が集計した。

注 8）浪江町の元町内拠点に位置付けられている施設には、漁港関連施設や墓 地などのさまざまな施設がある。そのため、本論文では、元町内拠点に位 置付けられている施設の中でも、日常的な生活に必要な住宅、教育、医療、 福祉、商業に係る施設を対象に整備状況を整理した。

注 9）新町内拠点制度が創設させる前であるが、新町内拠点と同様の地域を元 町内拠点に次ぐ拠点とする方向性が示されている。

注 10）都市計画区域マスタープランにて、浪江町および富岡町は都市拠点機 能に位置付けられている位置を、大熊町は商業業務拠点と位置付けられて いる位置を中心市街地とした。富岡町と大熊町は富岡都市計画区域に含ま れ、大熊町に都市機能拠点の位置づけがないことから商業業務拠点を中心 市街地として選定した。参考文献 29)32)

注 11）著者作成。地図は国土地理院国土数值情報から引用(参考文献 16)。元 町内拠点および新町内拠点の位置・範囲は、模式的に示しており、正確な 位置・範囲を示すものではない。中心市街地の位置は注 10)のとおり図示し た。元町内拠点、新町内拠点の位置・範囲は本研究で対象としている復興 計画等を参考として示した。

注 12）各町の帰還困難区域に占める新町内拠点面積の割合。各町の帰還困難 区域の面積は、参考文献 10)より引用

注 13）浪江町の新町内拠点は、3 地区のほかに文化的な価值のある施設とし て、「陶芸の杜おおぼり」等が指定されている。

注 14) Google Earth を用いて測定。原発事故前中心市街地に位置する JR 大 野駅と元町内拠点内に新設された大熊町役場新庁舎の直線距離。 


\section{Masayo FUKUDA ${ }^{* 1}$ and Noriko AKITA*2}

${ }^{* 1}$ Grad. Student, Graduate School of Horticulture, Chiba University, M.ph.
${ }^{* 2}$ Prof., Graduate School of Horticulture, Chiba University, Dr.Eng.

Long-term residence restrictions have been implemented in the evacuation areas caused by the Fukushima Dai-ich Nuclear Power Station Accident (hereinafter referring to as the nuclear accident). These nuclear accident-affected municipalities have proceeded with reconstruction in the face of uncertain situations in the future, such as resolving the nuclear accident, changes in radiation levels, and the outlook for national policies and system design, including evacuation orders.

Previous studies on nuclear accident-affected areas reported evaluating reconstruction projects, surveys of residents awareness, business resumption, and zoning methods. But no research has been found that analyzes the impact of residence restrictions due to the designation of evacuation areas on the reconstruction planning. The purpose of this study is to clarify the impact of the designation and lifting of evacuation areas and the residence restrictions on the content of disaster reconstruction plans, focusing on the hub. We covered Namie, Okuma, and Tomioka Towns, where the entire administrative area was under evacuation areas. And there is a much population in the areas where it is expected that residents will face difficulties in returning for a long time (hereinafter referring to as the difficult to returning areas). The purpose of this report is to clarify the impact of the designation and lifting of evacuation areas and the resulting residence restrictions on the content of municipal disaster reconstruction plans.

Residence restrictions contents in evacuation areas changed in three stages. First, it was prohibited to live or enter within a $20 \mathrm{~km}$ radius of the Fukushima Dai-ich Nuclear Power Station, the target municipalities areas, until the reorganization of the restricted areas. Second, after the reorganization, entry into the areas was allowed, but the residence was prohibited. Finally, once the evacuation orders were lifted, excluding difficult to returning areas, they were able to resident the towns. And the national government made the specified reconstruction and revitalization bases (hereinafter referring to as the specific bases) construction available in difficult to returning areas.

The location of the hub on disaster reconstruction plans changed by the content of residence restrictions. Target municipalities planned to make hubs in outdoor their towns in terms of inhibition entering their municipal areas. Once they were allowed to enter their municipal areas, they planned hub construction there. The national government lifted evacuation orders and made specific base constructions available in difficult to return areas, and they planned to build specific bases and the former ones. Iwaki City was selected as the relocation for the local government functions by target municipalities. Iwaki City is the hub for the Hamadori area of Fukushima Prefecture, which includes the target municipalities. It was clear that municipalities could not reconstruct the living environment in their areas choose a hub within a wide area to rebuild lives.

Furthermore, Namie and Tomioka Towns, where the radiation level was low in the central urban areas, developed hubs in the areas. While Okuma town, where the central urban areas became difficult to return areas, set hub away. In both cases, target municipalities consolidated and implemented public disaster housing and public facilities under the policy of compact cities. On the other hand, it is possible to build specific bases to be not in line with the approach of compact cities. It is difficult to envision establishing the second base in a small municipality like the target municipalities. 